\title{
体育场馆室内装修及地下室防水工程监理工作探讨
}

\author{
吴霞辉 \\ 浙江东方工程管理有限公司
}

DOI:10.32629/btr.v1i5.1644

[摘 要] 中国的体育,社会主义中国的体育,主要说就是面向群众的体育,就是为了人们的身心愉悦和身体健康着想。体育场馆 装修在我国体育事业中是不可或缺的重要元素,所以我国在这方面也加大資金和资源的投入,为我国的体育事业铺平道路。我 国建筑的数量不断增加,但同时也带来了各种施工质量问题,例如建筑地下室渗漏情况是最普遍的。尤其是对于体育馆这种公 共设施场所来说, 一旦出现地下室渗漏问题, 必然影响体育场馆的正常使用。本文就体育场馆的室内装修和地下室防水工程的 监理工作进行了探讨。

[关键词] 体育场馆；地下室；防水工程渗漏；装修；监理工作

体育场馆现在的数量在不断增多, 主要就是人们对健康 的重视越来越高。并且对体育运动项目要求越来越多, 不过 在对体育馆装修的时候, 为了确保相应的效果, 那么就应该 对体育馆的具体结构有所了解, 同时在对体育馆装修的时候, 还应该要对具体细节有所了解。当然在这个时候, 对体育馆 装修及地下室防水工程的了解, 它同样也显得非常重要。

\section{1 体育场馆装修的优点}

体育场馆的建设积极的推动了城市的发展和社会经济 的发展, 而体育场馆设施的建设可以让人们对城市生活更加 的完善有内涵, 中国要的是它能节约城市空间, 间接的改善 城市内的交通环境。体育场馆的建设在国际上也是一个非常 重要的话题, 加强体育场馆装修力度, 让我国的体育事业蒸 蒸日上, 逐渐的跟上时代的步伐, 走向社会的前列, 为我国的 体育事业做好更大的铺垫。

\section{2 体育场馆装修施工监理工作的注意事项}

2.1 施工日期的管理

我国对于体育场馆装修施工有着非常重要的要求, 所以 在进行施工时应该严格按照最初规定的时间, 尽量使工作的 时间段和总日期不要造成太大的偏差。首先施工的工人的素 质会给施工期长短造成影响, 因此在进行体育场馆装修施工 时, 需要要选择比较专业的施工人员或者是有着现场施工经 验的, 技术娴熟的工作人员, 或者在进行装修施工工作前, 对 装修人员将进行严格的培训, 挑选出工作能级较强, 工作积 极性高的人员来进行装修工作, 保证在用人方面不会造成太 大的时间损失, 进而大大的提高了施工效率。其次, 设计人员 与施工人员应该积极的合作, 设计人员在本职工作上不可以 解怠, 设计图纸的勾画和审查应该积极的完成, 还要和施工 人员进行详细的讲解, 施工人员应该自己审视设计人员的图 纸, 有不便施工或图纸错误的地方应该积极的和设计人员进 行商讨并及时改正, 这样既加深了工作人员之间的默契度, 又大大的节约了施工的时间, 为能在规定的时间内完成装修 工作奠定了坚实的基础。最后, 各项体育场馆装修工组人员 之间都他应该主动配合, 并且在自己的本职工作各方面尽量
做到更最好, 积极合作是各个行业必须的条件, 努力做到这 几点, 是体育场馆装修工作顺利有效的完成的重要步骤。

2.2 对装修施工工作管理的科学性

体育场馆装修施工管理的科学性主要表现在两个方面。 一方面, 现场中的施工人员应该在施工场地配备先进的测量 仪器是测量更加的准确更加的科学, 测量仪器应该选用在出 厂前做好各种检验的没有瑕疵的仪器, 在测量仪器优秀的基 础上运用先进的计算机技术进行辅助测量和精准的计算, 保 证装修施工过程中数据上面的准确性和严谨性也更好的避 免了装修效果, 差需要重新规整装修的问题。另一方面, 装修 施工监管人员应该努力做好本职的工作, 对于每项装修方面 的工作要尽量的做到细致的监工, 及时的发现和解决问题。 另外, 监管人员还需要加强对施工人员的管理, 及时谴责急 慢工程, 违反施工规定的施工人员, 并制定一些合理的惩罚 制度, 保证施工工作的科学性、严谨性。

\section{3 施工造价的节约控制}

在体育场馆装修施工过程中, 工程造价的管理控制是非 常重要的方面之一。在施工工作之前提前安排好大致的工作 曲线使各个施工环节有效而且紧密的连接起来, 使施工效率 有效的提高起来。装修设计方面的严谨性, 加之在计算方面 的准确性, 使其在施工过程中减少了重新拆除改正和一些不 必要的材料浪费, 还可以用一些剩余材料进行补缺, 尽最大 可能做到物尽其用, 使得投资发挥到最佳的效益和效果。

2.4 施工的文明性以及环境保护

在社会工作中, 任何一项施工工程都会或多或少的造成 一些污染, 我们应该尽量避免或减少这一状况。首先, 施工过 程中经常会使用一些对环境有害的材料, 因此在装修施工完 后, 应该及时对其进行处理或在施工过程中随手处理掉。其 次, 在装修材料的选择上应该着重注意起来, 尽量先选择绿 色无污染环保型的材料, 而在灯光、点暖气等方面采用节能 环保的材料。最后在装修过程中不可避免的会出现一些预料 之外的状况, 对于此施工管理人员应该及时做好预测以及应 对措施使我国的空气、水资源减少污染。文明的施工才能保 
障装修施工安全, 绿色的进行。

\section{3.体育场馆地下室防水工程的监理工作}

由于体育场馆的特殊功能要求, 在地下室的防水工程中 有了更高的要求, 采取因地制宜的综合治理方案。但是由于 一些技术、施工等方面的原因, 混凝土结构受损、钢筋腐蚀 的情况普遍存在。

3.1 施工设计的技术优化

在设计方面, 由于施工方案的合理确定作用显著, 尤其 是在图纸设计环节, 需要清除地确定地下室防水的抗渗级别 和施工详细要求, 并完成土质的设计。例如荷载引起的裂缝 具有显著的危害, 直接影响到结构的承载力, 此时在图纸设 计当中就应该考虑到结构变形的计算, 以便于减少各种不利 条件引起的变形, 以此为基础提升混凝土的抗拉强度。此外, 在底板设计、抗变形、抗沉降能力方面也应该从设计的角度 出发, 确定合理的外加剂参量与混凝土配合比, 做好施工前 期的规划工作。对于防水层的设计, 为了避免防水混凝土表 面出现毛细孔与渗水问题, 应控制好其宽度与密封层的结合 情况, 具备不透水、抗变形、耐腐蚀的能力。

\section{2 施工方案的合理选择}

(1) 化学灌浆堵漏。这种方式可以选择氰凝材料进行, 在预聚体内掺入表面活性剂, 在搅拌均匀后与水发生化学反 应, 生成不溶于水的凝胶体, 同时释放二氧化碳。在堵漏施工 方面, 需要进行压水试验、灌浆、封孔等。例如灌浆孔的间 距控制在 $1 \mathrm{~m}$, 灌浆结束后拔出灌浆嘴, 利用水泥砂浆密封灌 浆孔。如果有明显的孔洞与缝隙, 那么需逐个进行止水处理, 例如可于背水面涂刮聚合物水泥素浆, 使表面形成一层不透 水的覆盖层, 起到防渗作用, 并除去表面油污, 让防水层更加 牢固。

(2) 施工缝处理。施工缝是目前地下室防水工程的薄弱 部位, 此时地面混凝土要进行连续浇筑, 保障施工缝的准确 性。而施工缝一旦设置, 必须要配合设置止水带。止水带的 两侧需要放置松动、损伤, 在牢固连接后清理接缝处的残渣, 使用水泥砂浆施工。需要注意的是墙体、顶板、底板不可留 有施工缝, 如果墙体带孔, 也应该控制好孔的距离, 且不可将 施工缝设置在墙板受剪力较大的区域内。然后在不漏水部位 按照材料使用要求, 大面积涂抹聚合物水泥防水砂浆, 需分
层抹压, 顺序为防水素浆一防水砂浆一防水素浆, 最后拨管 堵水。对于混凝土轻微渗水, 可用无机速凝止水材料涂抹在 混凝土表面, 戴橡皮手套反复揉搓, 直至不见水影为止。

(3) 后浇带施工。建筑板、墙区域都可以设置沉降后浇 带。当地下室施工沉降相对稳定时, 可以待两侧混凝土施工 完成一段时间后, 再清理接缝处混凝土, 涂抹水泥砂浆, 进行 后浇带施工。另外, 混凝土要一次浇筑完毕, 并及时做好覆盖 保护措施, 在保持混凝土湿润的前提下进行为期 1 个月左右 的养护工作。

\section{3 材料质量控制}

在材料质量控制上, 首要考虑的因素就是混凝土的配合 比设计与骨料的添加, 以此提升混凝土比例, 改善结构的抗 渗性能。例如在混凝土振捣方面就要防止漏振, 还需要注重 振捣从后至前的顺序。而材料控制的关键在于防水材料的管 理。工程施工可能会使用多种防水材料, 此时施工方应对材 料进行质量管控, 在材料符合设计标准时才可以进行使用。 这些工作也需要良好的监督检查和质量控制方案作为基础, 尤其是在施工初期时要注重对材料的储存与保护, 防止出现 过度的自然损耗, 影响材料性能。

\section{4 结束语}

随着经济社会的迅速发展, 人们的生活水平日益提高, 人们对体育需求日益增长但是体育基础设施建设却相对滞 后, 而日益增长的精神文化需要与体育基础设施的现状不相 适应, 尤其是多功能、高档的公共体育活动设施缺乏, 不能满 足人们多层次的体育活动需要, 不能满足国家体育发展事业 的要求。因而在体育场馆的建设环节中, 需要做好质量控制 方案, 在施工技术、设计方案与施工材料选择方面进行严格 把控, 达到预期的施工效果。

\section{[参考文献]}

[1]陈国运.地下室卷材防水层施工质量问题及预防措 施探析[J].科技创新与应用,2012,(11):201.

[2]张振宇,薛建华.浅谈地下室防水工程细部渗漏的主 要原因与对策[J].价值工程,2014,33(20):126-127.

[3]黄维宇.体育场馆装修施工管理 [J]. 装饰装修天 地,2018,(13):9. 